\begin{tabular}{|c|l|}
\hline Title & Itai-Itai disease and the countermeasures against cadmium pollution by the Kamioka mine \\
\hline Author(s) & Yoshida, Fumikazu \\
\hline Citation & Environmental Economics and Policy Studies, 2(3), 215-229 \\
\hline Issue Date & 1999 \\
\hline Doc URL & http://hdl.handle.net/2115/53361 \\
\hline Type & article (author version) \\
\hline File Information & itai-itai.pdf \\
\hline
\end{tabular}

Instructions for use 


\title{
Itai-Itai disease and the countermeasures against cadmium pollution by the Kamioka mine
}

\section{Fumikazu Yoshida/ Akio Hata/ and Haruo Tonegawa}

\begin{abstract}
The Itai-Itai disease case is one of four major pollution-related lawsuits occurring in Japan after World War H. This paper, which is based on investigations of the pollution source, the Kamioka mine, considers (1) the history of the disturbances to the environment caused by the Kamioka mine; (2) the Itai-Itai disease suit; (3) the pollution nprevention measures and methods of the Kamioka mine and refinery; (4) the reduction of cadmium pollution in the Jinzu River; and (5) the actual application of the "polluter pays principle". The authors conclude that the court decision and the agreements between the victims and Mitsui Mining made it possible to control and reduce the damage caused by cadmium pollution and four additional, contributory factors.
\end{abstract}

Key words: Itai-Itai disease, Cadmium pollution, Kamioka mine, Countermeasures, Polluter pays principle (PPP)

\section{Introduction}

Osteomalacia, softening of the bones as a result of renal tubular dysfunction, is now commonly known as Itai-Itai disease. It attacks women who have borne several children; during its final stages, when patients can neither stand, walk, nor talk, all they say is "itai-itai" (Japanese for "It hurts! It hurts!")-hence its common name. In one of the worst cases, a patient lost $30 \mathrm{~cm}$ as a result of pressure fractures of the vertebrae; and another patient suffered many fractures, 28 in the ribs alone.

The issue was recognized as serious when cases of Itai-Itai disease and renal tubular dysfunction were found among residents in a number of cadmium polluted areas throughout Japan, most seriously in the district of Toyama near the Jintsu River but also in Tsushima, Nagasaki Prefecture, the Kakehashi River basin in Ishikawa Prefecture, and the !chi River basin in Hyogo Prefecture.

The Japanese people have higher levels of daily cadmium intake and a higher concentration of cadmium in the renal cortex than any other group of people in the world. Because high cadmium levels have been found in rice grains, it is reasonable to suppose that this is the route by which cadmium enters the human body, from which it follows that the problem of toxic 
pollution by cadmium is not confined to the locality in which the cadmium was originally dispersed into the soil.

In 1972 victims of Itai-Itai disease living in the Toyama district brought a case against the main polluters (the Mitsui Mining and Smelting Co.). After the court had reached a decision and made a judgment against Mitsui, the victims and the corporation held negotiations and agreed on three points: (1) that compensation should be paid to the sufferers of Itai-Itai disease; (2) that compensation should be paid to those whose fields and crops had been polluted, as well as . compensating them for the detoxification of contaminated farm soil; and (3) that pollution prevention systems should be installed at the Kamioka mine and refinery. This last requirement has proved to be the most effective of the measures taken, as the company agreed to allow the victims, their lawyers, and interested scientists to survey and inspect the facilities without hindrance and at the company's expense.

Subsequently, sufferers, lawyers, and scientists, every year from 1972, have carried out an annual inspection of the Kamioka mine and refinery. In particular, the unhampered on-site inspections, the collection of data and disclosure of information about the types of material involved in the process, updated reports on the quality of process water and the conditions of drainage and emission, and the state of the soil, groundwater, and by-products have been powerful measures in preventing further pollution.

This paper, which is based on the reports of those inspections, considers the following issues: (1) the history of the disturbances to the environment caused by the Kamioka mine; (2) the Itai-Itai disease suit; (3) the pollution prevention measures and methods operated by the Kamioka mine and refinery; (4) the reduction of cadmium pollution in the Jinzu River; and (5) application of the polluter pays principle.

\section{History of environmental damage caused by the Kamioka mine}

In general, a mining operation consists of three stages: (1) the mining process; (2) the ore dressing process; and (3) the refinery process. All three stages have an effect on the environment. Although the metal-mining industry has played an important role in the modernization of Japan, the extensive development of the industry has also been responsible for many instances of environmental disturbance and damage.

In 1874 the Mitsui Corporation bought the Kamioka mine; in 1886 it introduced modern technology; and in 1889 it brought all the Kamioka mine operations under the umbrella of one administration. Within a year (in 1890), the local air was sufficiently polluted by White's rotary furnaces for the residents of Kamioka Town to lodge a complaint: This was the first instance of a formal protest by residents.

Since 1905 the main work of the pit has been the mining of zinc ore, which from the beginning 
required the development of technology to treat the poorer quality ore and to refine its dressing process. In 1909 Mitsui Corporation installed Potter's preferential flotation system to cope with its ore-dressing process. As means to treat the poor zinc ore were developed, the amount of ore increased, and the preferential system resulted in finer particles of tailing. The tailing slurry was thrown into the Jinzu River and was then precipitated in the rice paddies of the Toyama district. At the same time, the first cases of people suffering from Itai-Itai disease were reported.

After 1931 the organization representing the farmers, peasants, and fishermen of the Jinzu River basin repeatedly asked the Mitsui Mining Corporation to furnish proper facilities to prevent pollution; in response, Mitsui built its first tailing dam in the Shikamadani Valley (1931). The period of war, 1930-1945, saw a fourfold increase in the production not only of zinc but of zinc waste, which meant that more extensive areas of land in the Toyama district in and around the Jinzu River basin became contaminated.

Although the main aims of the "innovations" introduced after World War 11 (mass production and the saving of manpower) were designed to effect speedy restoration of the Kamioka mine and stimulate high economic growth, it took nearly 10 years for the Kamioka mine to reach prewar production levels.

As time went on, further innovations were introduced. In 1966 a significant change was made in the method of dressing ore: Instead of the direct bulk differential flotation process it had employed until then, the company adopted integrated bulk differential flotation. This process markedly increased the amount of ore-dressing treatment undertaken, which in turn led to a massive increase in tailing waste, with particles far finer than before. Because insufficient measures had been taken to prevent the random disposal of tailing waste (an earlier example of which was the collapse of the tailing dam at Wasabo in 1956), this inevitably led to a severe increase in pollution emanating from the Kamioka mine.

Although installation in 1944 of a German zinc electrolysis plant was intended to assist the recovery of cadmium, the period of high economic growth during the 1960s saw the production of vastly increased amounts of treated ore. The total loss of cadmium from the main processes of the Kamioka mine and refinery reached its highest recorded levels in 1970 (Kurachi et al. 1979).

\section{Itai-Itai disease suit}

When, after the end of World War 11, Dr. Noboru Ragino, a physician of Fuchu Town, Toyama Prefecture, reopened his private clinic in the town, he was alarmed by the number of patients who came to see him suffering from particularly severe, painful attacks of osteomalacia. It was not until 1955, however, that he and Dr. Minoru Kohno alerted the general public to the nature of Itai-Itai disease. 
Although over the next 2 years a number of reports were published insisting that the osteomalacia was simply the result of vitamin deficiency, Dr. Hagino continued to investigate the possibility that other causes were responsible. He strongly suspected that the hazardous outflow from the Kamioka mine was a likely source of the disease because the area of agricultural land contaminated by the Kamioka mine perfectly overlapped the area from which the afflicted patients came.

In 1961, after Dr. Jun Kobayashi had published his data on the cadmium content of rice obtained from the contaminated land, Dr. Hagino and Dr. Kin-ichi Yoshioka published a report that set out to show that cadmium played an etiological role in the development of Itai-Itai disease. Two years later, in 1963, the Ministry of Health and Welfare instituted a study group to inquire into the disease. The group published its report in 1966, concluding that, in conjunction with other factors such as nutritional deficiencies, cadmium was one of the causes of Itai-Itai disease.

The victims were not happy with this report, and that same year they set up an organization (Task Force on Itai-Itai Disease) to ensure that the real culprit, cadmium, should be publicly acknowledged. In 1967 the task force entered into negotiations with the Mitsui Mining and Smelting Co., but nothing fruitful emerged from the discussions.

It appeared to the task force that the political and administrative approaches were likely to remain closed, so it decided, as a last resort, to take legal action. Supported by local residents and local government (town), more than 300 lawyers from all over Japan were organized to present the suit, which they filed against the Mitsui Corporation, basing it on Article 109 of the Mining Law, which covers a polluter's strict liability (Gresser and Morishima 1981). Soon after the appeal was brought to court, the Ministry of Health and Welfare declared that "Itai-Itai disease is caused by chronic cadmium poisoning during times of pregnancy, lactation, or when there is an imbalance of internal secretion, aging, a lack of calcium, etc."

In 1971, the Toyama district court handed down a decision that accepted the victims' claims as proven. Although Mitsui Mining and Smelting Co. appealed the decision to the Nagoya High Court and disputed the causality, the verdict for the victims was upheld. On the basis of this decision, Mitsui Corporation made reparations to more than 200 individuals suffering from the disease (Lawyers for Itai-Itai Disease Sufferers 1971-1974).

\section{Pollution prevention after the "ltai-Itai disease suit"}

Since 1972 the sufferers, lawyers, and interested scientific parties have carried out inspections of the Kamioka mine and refinery. The first two inspections revealed that: (1) the total amount of cadmium being discharged into the Jinzu-Takahara River was $35 \mathrm{~kg} / \mathrm{month}$ (1972); (2) the 
total amount of cadmium being discharged into the air was 5kg/month (1972); (3) although both Mitsui and the agents for the victims checked the same samples, the data did not always coincide, so it could not be accepted as an accurate measurement; (4) discharge from abandoned mines had extensively polluted the Jinzu-Takahara River (Coalition of Sufferers by Cadmium along the Jinzu River Basin and Investigation Committees 1978).

Five working groups were organized to carry out remedial measures, which included the following.

1 Controlling the effluent from the Kamioka mine and refinery (Kyoto University)

2 Controlling smoke emissions from the Kamioka refinery (Nagoya University)

3 Monitoring the balance of materials at the Kamioka refinery (Tokyo University)

4 Monitoring the sedimentation and outflow of heavy metal into the Jinzu-Takahara River system

(Toyama University)

5 Monitoring the structural stability of the tailing dams at the Kamioka mine (Kanazawa University)

The Kamioka mine, the largest zinc mine in Japan, is located midway along the northwest coast of Japan's crescent-shaped main island, Honshu (Fig. 1). Two plants employ a bulk-differential flotation process to refine the crude ore from the mine to lead, zinc, copper, and graphite concentrates. The lead concentrates are roasted and sintered, after which the coarse sinter is fed into a blast furnace. The crude lead is refined in electrolysis cells. The by-products of the lead refinery are gold, silver, and bismuth. The zinc concentrates are roasted into zinc calcine, which is then leached and refined in electrolysis cells. The by-products of the zinc refinery are sulfuric acid and cadmium.

As a result of closure of its Mozumi mine, the Kamioka Mine and Smelting Co. has recently changed the material used in its lead refinery processes from lead to lead batteries, and it has begun to import zinc ore from the Huanzala mine in Peru.

The effluent from kamioka mine is managed as follows: The average amount of water drawn from the mine is about $100000 \mathrm{~m}^{3} /$ day. The mine water is divided into two grades: clear water and muddy water. The tailing slurry from the ore dressing mills is pumped out to the dam; and about half of the polluted water is recycled at the mills. After the tailing slurry has been separated into slime and sand, it is dumped onto the river bank or into standing water; about half of the effluent from the tailing slurry is reused.

Drainage of effluent and waste water from the kamioka mine and refinery is monitored at eight authorized checkpoints: (1) the Wasabo tailing dam; (2) the Rokuro zinc plant; (3) the Shikama ore dressing, lead, and sulfuric acid plant; (4) the Shikamadani tailing dam; (5) the Atotsu audit mouth; (6) the Otsuyama audit mouth; (7) the Masutani tailing dam; and (8) the Mozumi ore dressing plant (Fig. 2).

The total amount of effluent water is $110000 \mathrm{~m}^{3} /$ day. Thanks to the separation of clear from 
muddy water, the recycling of process water at the ore dressing plant and the electrolysis cells, and an improvement in the process of the wastewater, the total amount of cadmium discharged has been reduced from $35 \mathrm{~kg} /$ month (1972) to 5kg/month (1997) (Fig. 3). At the same time, recycling the process water has brought about a savings of both materials and reagents; and OAkg/month in 1997. Apart from any unpredictable consequences that might result from a strong earthquake, scientists have ensured the stability and structural safety of the tailing dam.

\section{Reduction of cadmium pollution in the Jinzu River}

The Jinzu River, called the Takahara River at its source, arises in the Hida Mountains, an area affected by heavy winter snow. The river flows northward toward the Japan Sea (Fig. 1). The background cadmium level of the upper eaches of the Jinzu-Takahara River, unpolluted by the

Kamioka mine, is never more than $0.1 \mathrm{ppb}$. The cadmium level downstream of the Kamioka mine, on the other hand, can be as high as 10ppb

The total amount of known cadmium discharge from the eight authorized drainage points is about $5 \mathrm{mg} / \mathrm{s}$, and it is $1-3 \mathrm{mg} / \mathrm{s}$ from the abandoned mines. At the Shin-Inotani Dam, however, which is located downstream of the Kamioka mine, the cadmium discharge into the river water can be as high as several tens of milligrams per second.

Attention was therefore paid to locating other likely, although at that time that runs underneath the zinc electrolysis plant from a nearby power station. unconfirmed, sources of pollution. The chief suspect was an underground tunnel that runs underneath the zinc electrolysis plant from a nearby power station. Measurements taken in 1977 revealed that the cadmium discharged from this channel accounted for as much as $70 \%$ of the pollutants from all outlets. At the same time, the quality of the groundwater from the drilling wells at the Rokuro electrolysis plant suggested that the plant might be an even more serious source of contaminants. Thorough investigation into the cause of the pollution linked to the underground tunnel and measures taken to counteract groundwater pollution have been both the most important and the most difficult items on the agenda for 20 years.

When the underground channel was inspected, it was found that groundwater with a high cadmium content issued from (1) an open sewer at Rokuro, (2) the drainage pond of the Higashimachi power station, and (3) the Rokuro dumping yard (Fig. 4). The Kamioka Mining and Smelting Co. therefore agreed to take action to protect the groundwater system from pollution to: (1) prevent leakage of contaminated groundwater into the channel; (2) pump up the contaminated groundwater through a recovery well; (3) cut off the infiltration of Rokuro Valley water into the ground; (4) analyze the quality of the groundwater at the site of the Rokuro electrolysis plant; and (5) repair or renew the floor and tanks of the Rokuro plant (Fig. 4). 
Although as a result of these measures cadmium discharge from the channel fell from 21 $\mathrm{kg} /$ month in 1977 to $7 \mathrm{~kg} /$ month by 1980, during the period 1980-1990 the cadmium discharge did not change (Fig. 3). Hence in 1990 the Itai-Itai disease sufferers requested that the old electrolysis plant be rebuilt. The following year, 1991, the company spent $¥ 6$ million to reconstruct the electrolysis plant with the aid of Belgium technology.

During the reconstruction it was discovered that the soil under the new plant, which was built alongside the old plant, was also severely contaminated with cadmium and zinc. The company therefore drilled cores at 15 sites to survey the contaminated soil and groundwater. On the basis of this survey, they have extended the recovery tunnel, which, for the purpose of pumping up the groundwater, was excavated along the eastern margin of the polluted area.

Use of the tunnel and the operation of the new plant have brought about a reduction of around 2-3 kg/month in the cadmium discharge. After 1995 the company spent $¥ 90$ million to pump up the contaminated groundwater in the Hokuriku Electric Power Company channel. As a result of these measures, the cadmium discharge from the Hokuriku Electric Power Company channel dropped $0.3 \mathrm{~kg} /$ month after 1996 (Fig. 3). The mean concentration of cadmium in the river water at the Jinzu third dam fell from 1.5ppb in 1968 to 0.16ppb in 1977. After 1980 the mean concentrations of cadmium in river water at the Jinzu first dam and the Ushigakubi irrigation canal have been 0.1-0.2ppb, which is approaching the background level of cadmium found in the nonpolluted area since 1988.

Because the cadmium discharge from the Hokuriku Electric Power Company channel fell to about $0 \mathrm{~kg} /$ month after 1996, the mean concentration of cadmium in river water anywhere along the Jinzu River was $0.1 \mathrm{ppb}$ level (Fig. 5). The mean concentration of cadmium found in sediment at the Jinzu first dam fell from 16-18 ppm in 1968 to $1.39 \mathrm{ppm}$ in 1976. Although since 1986 the level has been less than 1ppm, this figure is slightly higher than that found in the nonpolluted area (less than $0.5 \mathrm{ppm}$ ).

\section{Situation of the "polluter pays principle"}

During the summer of 1972, the Itai-Itai disease case was finally settled, and the victims came to an agreement with Mitsui Mining and Smelting Co. As a result of the agreement soil prevention measures were put into operation; but things did not go as smoothly as had been expected. This was because the assessors were obliged to designate an area and make a plan to begin soil pollution prevention as a public works measure. As a result, between 1974 and 1977 more than four attempts were initiated to designate land as soil pollution prevention areas, progressing from the first attempt when 1500ha was designated to the third attempt when more than 1000 ha was stipulated for soil dressing. There was, however, a "rollback" against the view of the Ministry of Health and Welfare on the cause of Itai-Itai disease, and consequently the 
local government of Toyama Prefecture, which had planned the land use project, drastically changed its plans for paddy fields contaminated by cadmium. The result was a delay in the public works project. As for the cause of Itai-Itai disease itself, the International Symposium on Itai-Itai Disease, Environmental Cadmium Pollution and Countermeasures, held at Toyama in May 1998, reconfirmed that Itai-Itai disease is indeed caused by cadmium poisoning (Abstracts of communications, international symposium on Itai-Itai disease, environmental cadmium pollution and countermeasures 1998).

At this point we need to clarify the roles played in this affair by the local governments, and we must therefore distinguish between the town or city government and the prefectural government. Because they have different allegiances, they sometimes act at cross purposes. The town or city governments, being closer to their constituencies, tend to support the victims by both political and financial means. The prefectural governments, on the other hand, are more sensitive to (and more easily swayed by) powerful pressure from industry and from the guidelines laid down by the central governments; hence their policies do not always favor the victims.

The first pilot scheme (Table 1), which was undertaken from the fiscal year 1979 to the fiscal year 1984, covered a small area of only 90ha, amounting to approximately ¥2.4 billion in business expenses, with the share to be borne by the industry fixed at a rate of $35.15 \%$, equal approximately to $¥ 0.88$ billion. From fiscal year 1983 to fiscal year 1994, more public works projects covering 441 ha with expenses of $¥ 12.4$ billion were planned; but owing to the revision and reduction of the project in the middle of its operation, the project was cut to cover 356 ha, and the cost was cut to approximately $¥ 10$ billion; the proportion of the cost to be borne by the industry rose slightly to $39.39 \%$, equivalent to $¥ 4$ billion (Table 1 ).

A third area of the 437 ha was next designated for treatment from the fiscal year 1992 to the fiscal year 2004, at a cost of $¥ 25.5$ billion, with the entrepreneur bearing $39.39 \%$ of the burden (Table 1), equivalent to approximately $¥ 10$ billion, although the converted land excluding agricultural land eventually extended to 563ha.

The reason for the increase in the land area to be converted in the third district selected for reclamation was the result of an increase in the area of land the local authorities planned to sell as a site for a housing complex and industrial plants. This decision, however, led to the question that had been previously overlooked: Who would take over and utilize the decontaminated land because once the land

Now, although more than 30 years have passed since the Itai-Itai disease case was brought before the court, the Toyama prefectural government and Mitsui Mining and Smelting have succeeded in postponing any further measures to prevent soil pollution and have also succeeded in reducing both the area designated for soil restoration and the ratio of expenses to be borne by the entrepreneur. 
With regard to the polluter pays principle, the situation as it relates to Mitsui Mining and Smelting is this: On August 10, 1972 Mitsui Mining and Smelting made an agreement with the victims' organization with regard to the following items: (1) compensation for Itai-Itai disease victims; (2) clean-up of soil pollution; and (3) prevention of further pollution. Compensation paid by Mitsui Mining and Smelting based on item (1) was ¥3.7 billion overall, equivalent to $¥ 8.9$ billion in 1996; ¥1.5 billion for nursing allowances, equivalent to $¥ 2 A$ billion in 1996; $¥ 2.6$ billion for medical expenses, equivalent to $¥ 3.2$ billion in 1996 ; and $¥ 7.5$ billion in total equivalent to $¥ 14.6$ billion in 1996. Expenses for soil pollution prevention measures under item (2) were, as we have already seen, approximately $¥ 0.9$ billion for the first project, equivalent to approximately $¥ 1.1$ billion in 1996; approximately $¥ 4$ billion for the second project, equivalent to approximately $¥ 4.6$ billion in 1996; and $¥ 4.9$ billion altogether, equivalent to $¥ 5.7$ billion in 1996. Although approximately $¥ 10$ billion has been estimated for the third project, this figure is likely to be lowered before the project is completed. In addition, compensation for the suspension of planting and the reduction of rice production in paddy fields contaminated by cadmium by more than $1 \mathrm{ppm}$ amounted to $¥ 11.8$ billion altogether, equal to ¥14.1 billion in 1996. The total amount of compensation originally promised still exceeds the amount of money Mitsui Mining and Smelting has so far paid for soil pollution clean-up measures.

The accumulative total of expenses for the source measures based on the pollution prevention agreement came to ¥8.3 billion for drainage (¥11.8 billion in 1996), ¥3.2 billion for smoke treatment ( $¥ 5.0$ billion in 1996), and $¥ 0.5$ billion for treatment of closed and abandoned mines (¥0.8 in 1996), for a grand total of¥12.0 billion (¥17.6 billion in 1996) from 1970 to 1996 (Fig. 6). Additional expenses of an on-the-spot inspection came to approximately $¥ 0.2$ billion.

Many other issues that need to be considered-such as death and damaged health due to Itai-Itai and kidney disease caused by cadmium poisoningare hardly calculated here. For instance, the question of the amount of compensation to be paid to those with Itai-Itai disease mentioned in item (1) faces the difficult problem of how to estimate an amount that can compensate adequately for irreparable damage to health. As for the soil pollution prevention measures under item (2), the principle in the agreement that "the polluter pays the total amount of expenses necessary for the measures [to be] undertaken" has not been adhered to. As a result of the reduction in the area designated for restoration from 1500ha to 1000ha and reducing the entrepreneur's burden-bearing ratio to $35 \%$ or $39 \%$, Mitsui Mining and Smelting has been able to escape with an overall burden-bearing ratio of approximately $26 \%-27 \%$. In addition, although Mitsui Mining and Smelting compensated farmers for suspending their planting and for their reduced income, ¥11.8 billion in total (Table 2), rice contaminated by cadmium to levels of 0.4-1.0ppm was purchased by the government.

Because the special law for mining pollution control enabled the company to include 
investments intended for the treatment of closed and abandoned mines within its calculations for expenses to prevent pollution, the expenses allocated as measures to contain pollution at the source (item 3) were overcalculated to finance the company's compensatory undertakings (and obligations). Consequently, we should discount the expenses incurred by the Mitsui Mining and Smelting Co. as being truly burden-bearing. From 1972 to 1997, the monies paid out by Mitsui Company to compensate for the injuries incurred by Itai-Itai disease totaled ¥36.5 billion, which was $66 \%$ of the company's ordinary incomes ( $¥ 55$ billion) and $15 \%$ of its operating profit ( $¥ 245$ billion) (Yoshida 1998).

If we consider the conditions of the original agreement between Mitsui Mining and the victims-compensation for damages to health, soil restoration, and means to prevent pollution at the source-we note that in regard to soil restoration the Mitsui Company (abetted by the prefectural government) has not honored its obligations under the polluter pays principle, as its burden-bearing share has been greatly reduced owing to the cutback in the size of the area to be restored and in the burden-bearing ratio itself. This is because Mitsui Mining was able to apply the agricultural land soil prevention law and the law concerning the entrepreneur's bearing of the cost of public pollution control works to suit itself. Because the two laws merely draw a distinction between "natural" and "other source of pollution," the company was able to persuade the authorities to substitute public money for their own costs: that is, the central government and the local authorities (both town and prefecture) have provided a subsidy.

When it comes to measures to prevent pollution at the source, the company was successful in limiting expenses Although not, historically, being quite the same as the OECD's (Organization for Economic Cooperation and Development's) polluter pays principle (PPP), Japan's PPP nonetheless has the character of a legal liability, and it is therefore easy to combine this principle with the principle of causation and responsibility as it is embodied in the clause of the law concerning the entrepreneur's bearing of the cost of public pollution control works, which sets out "the degree of recognition as a case of pollution." By interpreting and applying this principle rather flexibly, however, the Japanese government has been able to use it as a tool to reduce the burden on the polluters.

Although not, historically, being quite the same as the OECD's (Organization for Economic Cooperation and Development's) polluter pays principle (PPP), Japan's PPP nonetheless has the character of a legal liability, and it is therefore easy to combine this principle with the principle of causation and responsibility as it is embodied in the clause of the law concerning the entrepreneur's bearing of the cost of public pollution control works, which sets out "the degree of recognition as a case of pollution." By interpreting and applying this principle rather flexibly, however, the Japanese government has been able to use it as a tool to reduce the burden on the polluters. 


\section{Conclusions}

If we consider that the restoration of land to its original condition entails, as a corollary, that the same pollution damage should never occur again, source prevention measures and soil pollution prevention measures are two of the main pillars supporting the recovery of land damaged by pollution. In this regard, Kamioka Mining and Smelting Co. source prevention measures, based on the pollution prevention agreement, have achieved a remarkable success by obtaining a natural background level of $0.1 \mathrm{ppb}$ of cadmium outflow to the downstream area. These efforts should be highly valued.

Although we have sought to make it clear that Mitsui Mining and Smelting Co. has, to a certain extent, managed to evade some of its obligations, the court decision and the agreements made between the victims and the company have nevertheless made it possible to control and subsequently reduce the physical and economic damage caused by cadmium pollution emanating from the Mitsui Kamioka mine. We draw attention to four contributory factors: (1) the geographical and administrative separation of the mine area and the homes and farms of the sufferers, which has meant that "company town" problems have been avoided (as when powerful companies "lean on" their employees to conform or risk losing their jobs and their homes); (2) a firm tie-up between the victims, who typically are rice farmers, and the local (town) government to assist the sufferers; (3) a more serious undertaking over the last 25 years by Mitsui Mining and Smelting Co. to listen to the victims and their lawyers and to pay attention to their requests; and (4) an improvement in Mitsui Kamioka Mining Co.'s attitude to the environment and an increased willingness to look after it (because the company's size gives it the technical means to do what it has a moral obligation to undertake), and to carry out the necessary "downsizing and restructuring" of its own plant. The outlook is therefore not entirely black.

\section{References}

Abstracts of communications, international symposium on Itai-Itai disease, environmental cadmium pollution and countermeasures, 1998, Toyama Coalition of Sufferers by Cadmium along the Jinzu River Basin and Investigation Committees (1978) Pollution prevention at the Kamioka mine, 1978, Toyama Friberg L (1974) Cadmium in the environment, 2nd edn. CRC Press, Cleveland, Ch 8 Gresser J, Morishima A (1981) Environmental law in Japan. MIT Press, Cambridge, MA, Ch 3 Hata A (1996) Pollution prevention of the Kamioka mine and refinery after the Itai-Itai Disease suit. Osaka ity Business Review, pp 1-15 Itai-Itai Disease Countermeasures Council (1982-1998) City UniversProceedings of seminar on Itai-Itai disease,

Toyama Kamioka Mining and Smelting Co. (1979-1997) Annual report of pollution prevention Kurachi M, Tonegawa H, Hata A, eds (1979) Mitsui Company and Itai-Itai disease. Ohtsuki Shoten, 
Tokyo Kurachi M (1989) A case study of restoration and prevention from cadmium pollution caused by zinc mine and refinery in Japan. In: Proceedings of international conference on base metals technology, pp 431--439

Lawyers for Itai-Itai Disease Sufferers (1971-1974) Documents of Itai-Itai disease suit, vols 1-6. Sogo Tosho, Tokyo Yoshida F (1998) Accumulative pollution and polluter pays principle. Econ J Hokkaido Univ, 27: 1134 